\title{
Prophylactic mastectomy for the prevention of breast cancer: Review of the literature
}

\author{
Rawan K. Alaofi, Mohammed O. Nassifi, Marwan R. Al-Hajeili²
}

Taibah University College of Medicine, Medina, Departments of ${ }^{1}$ Surgery and ${ }^{2}$ Medicine, King Abdulaziz University, Jeddah, Saudi Arabia

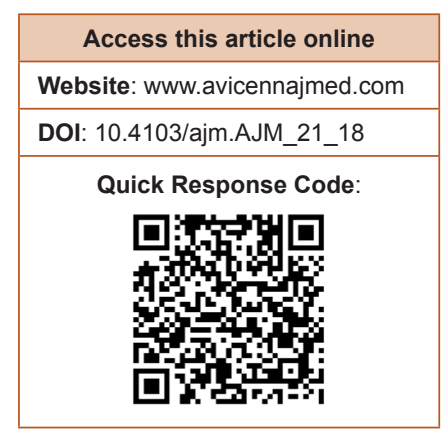

\section{ABSTRACT}

The high incidence and recurrence rate of breast cancer has influenced multiple strategies such as early detection with imaging, chemoprevention and surgical interventions that serve as preventive measures for women at high risk. Prophylactic mastectomy is one of the growing strategies of breast cancer risk reduction that is of a special importance for breast cancer gene mutation carriers. Women with personal history of cancerous breast lesions may consider ipsilateral or contralateral mastectomy as well. Existing data showed that mastectomy effectively reduces breast cancer risk. However, careful risk estimation is necessary to wisely select individuals who will benefit from preventing breast cancer.

Key words: BRCA, breast neoplasms, ductal carcinoma in situ, prophylactic mastectomy, risk reduction

\section{INTRODUCTION}

Breast cancer continues to be the most common cancer occurring in women with an annual incidence of 252,710 cases in the United States, resulting in 41,070 deaths, only second to lung cancer. ${ }^{[1]}$ The prevalence in 2014 had reached 3,346,387 cases with a probability of $12.4 \%$ for a women to be diagnosed with breast cancer during her lifetime that increases with age. ${ }^{[1,2]}$ Based on the surveillance, epidemiology, and end results (SEER) database, there has been a change in breast cancer incidence between the years 1975 and 2014. The reported annual percent changes in the years 1975-1980 and 2004-2014 were -0.5 and 0.3 , respectively. A surge of breast cancer incidence during the 1980s can be explained by changes in female reproductive patterns and the adoption of more aggressive screening techniques that have led to increased detection of the disease. ${ }^{[2]}$ Risk factors for developing breast cancer occurrence or recurrence are multiple and complex, including family history, genetic mutations, lifestyle, radiation exposure, parity, previous history, etc., The clinical features and the type of primary cancer treatment can affect the risk of the recurrence as well. ${ }^{[3]}$ In general, the rate of recurrence is higher in the first few years after the initial

Address for correspondence: Rawan K. Alaofi,

Taibah University College of Medicine, Medina, Saudi Arabia.

E-mail: rawanalaofi@gmail.com breast cancer diagnosis, and it drops down after that. ${ }^{[4]}$ Multiple strategies have been implemented to reduce the risk of breast cancer occurrence, and recurrence. These interventions include lifestyle modification, early detection with imaging, chemoprevention and surgical intervention. ${ }^{[3]}$ Prophylactic mastectomy is one of the growing strategies for breast cancer risk reduction. ${ }^{[5]}$ In this review, we are going to discuss the current evidence for prophylactic mastectomy in regard to types, indications and its role in breast cancer prevention.

\section{HIGH-RISK POPULATION}

Assessing breast cancer risk is based on both endogenous and exogenous factors. Mutations affecting known genes, compelling family history, having benign breast diseases with specific histologic features, previous history of breast cancer or radiation therapy to the breast all increase the

This is an open access journal, and articles are distributed under the terms of the Creative Commons Attribution-NonCommercial-ShareAlike 4.0 License, which allows others to remix, tweak, and build upon the work non-commercially, as long as appropriate credit is given and the new creations are licensed under the identical terms.

For reprints contact: reprints@medknow.com

Cite this article as: Alaofi RK, Nassif MO, Al-Hajeili MR. Prophylactic mastectomy for the prevention of breast cancer: Review of the literature. Avicenna J Med 2018;8:67-77. 
risk of developing breast cancer. Familial susceptibility to breast cancer accounts for $<25 \%$ of all breast cancer cases. ${ }^{[6]}$ Several genes have been implicated in familial cases. Mutations in breast cancer 1 (BRCA1) and breast cancer 2 (BRCA2) genes explain $20 \%$ of the familial clustering of breast cancer ${ }^{[6]}$ BRCA1 is a tumor suppressor gene mapped to chromosome 17. Its protein product is part of a complex compound responsible for repairing double-strand breaks in deoxyribonucleic acid (DNA) that contribute to genomic instability and drive cancer development. ${ }^{[7,8]}$ These breaks can be induced by radiation exposure or chemotherapy. ${ }^{[9]}$ BRCA2 gene is located on chromosome 13 and has a similar function to BRCA1 gene. ${ }^{[10,11]}$ These genes are important for the stability of the genome. The predisposed subject carries a defective allele of a tumor suppressor gene. Meanwhile, a second hit, a loss of the second gene copy, is a necessary step to cause tumor cell growth. ${ }^{[12]}$ Thus, women carrying BRCA1 or 2 gene mutations are thought to have a significantly higher risk of developing breast cancer, usually diagnosed at a younger age compared to general population. ${ }^{[13-16]}$ It is estimated that the average cumulative risk of breast cancer by age 70 years is $57 \%-65 \%$ for BRCA 1 gene mutation carriers and $45 \%-49 \%$ for BRCA2 gene mutation carriers with 20-times increase in the risk of breast cancer compared to general population. ${ }^{[13,14,17]}$ Similarly, mutations in other genes account for only a small fraction of the familial cases. The p53 gene is located on chromosome 17, and like BRCA, it is a tumor suppressor gene. Mutations in this gene are found in $50 \%$ of all cancer types. ${ }^{[18]}$ They are associated with a high lifetime risk of cancer and involved in $1 \%$ of hereditary breast cancer cases. ${ }^{[19]}$ The absolute lifetime risk of breast cancer in $\mathrm{p} 53$ gene mutation carriers is estimated to be $24 \% .{ }^{[20]}$ The phosphatase and tensin homolog (PTEN) gene located on chromosome 10 is widely expressed throughout the body. It regulates cell cycle and triggers apoptosis. Mutations in this gene underlie a number of tumor syndromes: Cowden syndrome, Bannayan-Riley-Ruvalcaba syndrome, and Proteus and Proteus-like syndromes. These syndromes increase the risks for several types of cancer, with female breast cancer being the highest. ${ }^{[21]}$ It is estimated that the absolute lifetime risk of breast cancer for PTEN mutation carriers is $25 \% .{ }^{[22]}$ Apart from familial susceptibility, sporadic cases that show no familial clustering are mainly due to the accumulation of poorly penetrant mutations in a number of genes affected by environmental factors. In general, genetic mutations are considered high risk for developing breast cancer when they show a 4 -fold increased risk of breast cancer in carriers compared to general population. Some benign breast diseases have been reported to increase the risk of subsequent development of breast cancer. Noticeably, the risk is higher with proliferative diseases than nonproliferative histological changes. A cohort of 4970 women with biopsy-proven benign breast diseases was studied retrospectively for the determination of subsequent development of breast cancer. ${ }^{[23]}$ The estimated overall breast cancer incidence rate was $452 / 100,000$ person years at risk. Age $>50$ years increased the risk by $80 \%$. Breast cancer risk was significantly higher in women with proliferative lesions with an incidence rate ratio of 1.7, reaching 5.0 in atypical ductal hyperplasia (ADH). Similarly, the relative risk associated with nonproliferative lesions was estimated to be 1.28 , compared to 1.88 for proliferative lesions and 4.24 for atypia. However, women with nonproliferative lesions and negative family history showed no increased risk. ${ }^{[24]}$ The results of two other studies are consistent with the previous study and show comparable estimates of the risk ranging from 1.6 to 1.9 for women with proliferative disease without atypia and from 3.7 to 5.3 for atypical hyperplasia, all compared to women having nonproliferative lesions. They also reported elevated risk associated with calcification in proliferative lesions and in premenopausal women with atypical hyperplasia. ${ }^{[25,26]}$ Estimated 10-year cancer risks were $17.3 \%$ with $\mathrm{ADH}$, $20.7 \%$ with atypical lobular hyperplasia, $23.7 \%$ with lobular carcinoma in situ (LCIS), and $26 \%$ with severe ADH. ${ }^{[27]}$ In addition to the benign breast diseases, ductal carcinoma in situ (DCIS) is a noninvasive breast cancer composed of malignant epithelial cells completely bounded by a basement membrane of mammary ducts, which typically does not metastasize to lymph nodes. The proportion of DCIS is about $20 \%$ of screening-detected breast cancers, and it carries a higher risk for developing invasive disease. ${ }^{[28,29]}$ One study found that low-grade DCIS has 9 times increased risk of developing cancer at the same site within 30 years after diagnosis (95\% confidence interval, 4.7-17). ${ }^{[30]}$ The final diagnosis of a group of 241 women who underwent a mastectomy following a preoperative biopsy showing DCIS revealed that $14 \%$ of the patients had microinvasive carcinoma, and $21 \%$ had invasive ductal carcinoma. ${ }^{[31]}$ An earlier study reported that $26 \%$ of the patients were found to have an invasive disease. ${ }^{[32]}$ Another similar study showed comparable results. ${ }^{[33]}$ The previous studies identified predictors correlated with infiltration and all agreed on palpable tumor and large size DCIS. Early thoracic radiation before the age 30 years is a significant risk factor of breast cancer. The Late Effect Study Group trail reported a 56.7-fold greater overall risk of breast cancer associated with prior mantle radiotherapy at young age compared to general population. ${ }^{[34]}$ Women treated for unilateral breast cancer have an increased risk to develop contralateral breast cancer with a 5 -fold increased incidence of new cancer compared to general population. ${ }^{[35-37]}$ The estimates are listed in Table 1. 


\begin{tabular}{lc}
\hline Table I: $R$ isk of developing breast cancer \\
BRCA genetic mutations & Cumulative risk by age 70 years (\%) \\
BRCAI & 65 \\
BRCA2 & 45 \\
Other genetic mutations & Absolute lifetime risk (\%) \\
p53 & 24 \\
PTEN & 25 \\
Histologic risk factors & 10 years risk (\%) \\
ADH & 17.3 \\
ALH & 20.7 \\
LCIS & 23.7 \\
Severe ADH & 26.0 \\
Other factors & Overall risk \\
Early thoracic radiation & $56.7-$ fold \\
Prior history of breast cancer & 5 -fold \\
\hline BRCA: Breast cancer, BRCAI: Breast cancer I, BRCA2: Breast cancer 2, PTEN: \\
Phosphatase and tensin homolog,ADH:Atypical ductal hyperplasia,ALH:Atypical \\
lobular hyperplasia, LCIS: Lobular carcinoma in situ
\end{tabular}

\section{PROPHYLACTIC MASTECTOMY}

The use of both prophylactic bilateral and contralateral mastectomies is steadily increasing in the United States. Prophylactic mastectomy may be bilateral in healthy women at a high risk of breast cancer, or unilateral if done for a noninvasive breast lesion or in addition to a therapeutic mastectomy in the contralateral breast. ${ }^{[5]}$ The rate of prophylactic mastectomy in women at a high-risk of breast cancer had increased during the years between 2004 and 2008 to reach $35.7 \%$ for bilateral mastectomy and $22.9 \%$ for contralateral mastectomy. ${ }^{[38,39]}$ Prophylactic mastectomy could be technically performed in different ways. ${ }^{[40]}$ Total mastectomy (also called simple mastectomy) is a procedure where the majority of the breast tissue including the nipple-areola complex is removed through an elliptical skin incision, but muscle tissue beneath the breast and axillary lymph nodes are spared. ${ }^{[5]}$ It is unlikely to eradicate all breast tissue; even though, all the visible breast tissue is removed. Some of the breast tissue can be unintentionally left underneath the skin, on the inframammary fold, or near the axilla fat pad. ${ }^{[4,41]}$ In addition to total mastectomy, skin-sparing mastectomy is a way to remove the breast tissue including the nipple-areolar complex through a periareolar incision leaving most of the skin over the breast intact. This facilitates reconstruction, and the skin of the breast is preserved with no scaring. ${ }^{[40]}$ As an extension of skin-sparing mastectomy, nipple-sparing mastectomy (also called total skin-sparing mastectomy) preserves the nipple-areola complex and the skin over the breast. ${ }^{[42]}$ This is usually achieved through an inframammary incision where the skin is carefully dissected off the breast until all the anatomic boundaries of the breast are reached, and the breast in its entirety is excised. It is important to avoid leaving any breast tissue behind the nipple-areola complex. This process is technically demanding and much effort is required to reach the uppermost deep boundaries of the breast through a small and far incision. ${ }^{[41,42]}$ Specific retractors with light sources may be used to facilitate the excision. ${ }^{[43]}$ Historically, skin-sparing mastectomy was preferred more commonly than total mastectomy. Today, total mastectomy is the preferred prophylactic procedure, because of the advantage of current nipple reconstruction techniques. ${ }^{[5,38]}$ Increased rate of postoperative complications in addition to the doubtable oncologic safety in nipple-sparing mastectomy created reluctance amongst some institutions and surgeons to adopt this technique. ${ }^{[4,45]}$ In general, there is still debate about the most appropriate type of mastectomy for high-risk women, and it should be carefully selected. ${ }^{[41,42]}$

\section{EFFICACY OF PROPHYLACTIC MASTECTOMY}

\section{Bilateral \\ Impact of bilateral prophylactic mastectomy on breast cancer incidence \\ BRCA}

In BRCA gene mutation carriers, several studies showed a significant reduction in the incidence of breast cancer occurring in women who underwent bilateral prophylactic mastectomies. In 2001, Meijers-Heijboer et al. ${ }^{[46]}$ conducted a prospective cohort study of 139 women carrying BRCA1 or 2 gene mutations. Seventy-six (55\%) of these women underwent prophylactic bilateral simple mastectomy, whereas the other 63 (45\%) women remained under surveillance. As a result of a mean follow-up period of 2.9 years, none of the 76 women who underwent prophylactic mastectomy developed breast cancer, compared to 8 breast cancer cases diagnosed in the group under surveillance (ratio of observed to expected cases, $1.2 ; 95 \%$ confidence interval, $0.4-3.7)$. In the same year, Hartmann et al. ${ }^{[47]}$ identified 26 women with BRCA 1 or 2 gene mutation from their previous retrospective cohort study of bilateral prophylactic mastectomies. None of the patients developed breast cancer during a median follow-up of 13.4 years after the prophylactic mastectomies. Using two models, these studies show an $85 \%$ to $100 \%$ risk reduction achieved by prophylactic mastectomy. In addition, in 2004, Rebbeck et al.$^{[48]}$ conducted a prospective cohort study of 483 women of the same risk group. One hundred and five of these women who underwent bilateral prophylactic mastectomy were compared to 378 controls who did not undergo prophylactic surgery. With a mean follow-up of 6.4 years, breast cancer was found in two patients (1.9\%) of the bilateral prophylactic mastectomy arm and in 184 (48.7\%) of the matched control arm, confirming $90 \%$ to $95 \%$ reduction in breast cancer risk after bilateral prophylactic mastectomy. In a recent large prospective cohort study, Domchek et al. ${ }^{[49]}$ assessed the relationship between 
prophylactic mastectomy and breast cancer outcomes in BRCA 1 and 2 gene mutation carriers. No breast cancers were seen in 257 women who underwent bilateral prophylactic mastectomy compared to $7 \%$ of women without the surgery over 3 years of follow-up, showing decreased risk of breast cancer in BRCA1 and 2 gene mutation carriers associated with bilateral prophylactic mastectomy. Moreover, in a study conducted in 2015, 63 women carrying BRCA1 or 1 gene mutation who underwent nipple-sparing prophylactic mastectomy reported no newly diagnosed breast cancers at a median follow-up of 26 months supporting the same conclusion. ${ }^{[44]}$

\section{Non-BRCA}

Regardless of the BRCA gene status, two retrospective cohort studies evaluated the efficacy of bilateral prophylactic mastectomy in women at high risk for breast cancer due to variable reasons. Hartmann et al. ${ }^{[50]}$ categorized 639 women who underwent bilateral mastectomy because of family history of breast cancer into moderated-risk and high-risk groups. Women in the high-risk group included women with a family history of breast cancer in one or more first-degree or second-degree relatives, who were diagnosed at an early age, had bilateral disease, males or had associated history of ovarian cancer. Otherwise, they would be categorized into the moderate-risk group. The study used a control group of sisters, and the Gail model to predict the number of cases of breast cancer in both cohorts. After a median follow-up of 14 years, bilateral prophylactic mastectomy was found to be associated with a reduction in the incidence of breast cancer by $90 \%$. In 2005 , Geiger et al. ${ }^{[5]}$ identified 276 women with family history of breast cancer in one or more first-degree or second-degree relatives, history of atypical hyperplasia or one or more biopsy with benign findings who had undergone bilateral prophylactic mastectomy and compared them to 196 women reflecting the age and geographic distribution who had not undergone the surgery. The results of this study show that breast cancer developed in $0.4 \%$ of the former group compared to $4 \%$ in the latter.

\section{Lobular carcinoma in situ}

LCIS is rarely managed by bilateral mastectomy. ${ }^{[52]}$ Only a few authors advocated it based on the equal risk of both breasts to develop invasive disease. ${ }^{[53]}$ In one study, 56 patients chose bilateral prophylactic mastectomy and all remained cancer free. That was compared to 1032 patients who remained under surveillance with or without chemoprevention where $14 \%$ developed breast cancer after a median follow-up of 81 months. Notably, patients who opt for mastectomy had a stronger family history. ${ }^{[52]}$
Impact of bilateral prophylactic mastectomy on breast cancer survival

Despite the confirmed reduction in breast cancer risk after bilateral prophylactic mastectomy, it is reasonable to question whether this preventive procedure results in improved overall survival in the light of modern detection and treatment modalities. In 1997, Schrag et al. ${ }^{[54]}$ compared prophylactic bilateral mastectomy with no prophylactic surgery among women carrying BRCA 1 or 2 gene mutation carriers. They calculated that 30 -year-old women gain from 2.9 to 5.3 years of life expectancy after bilateral prophylactic mastectomy on average. They also reported that increased age at the time of the procedure results in a declined gain in life expectancy reaching its minimal for 60-year-old women. In 2002, Grann et al ${ }^{[55]}$ conducted a similar simulated cohort of 30-year-old women carrying BRCA1 or 2 gene mutation using Markov model. They reported that these women could prolong their survival 3.5 years with bilateral prophylactic mastectomy with a decrease in benefit according to age. More recently, in 2010, Kurian et al. ${ }^{[56]}$ developed a Monte Carlo model to simulate and compare different strategies for reducing cancer mortality in BRCA 1 and 2 gene mutation carriers. This study reported that in BRCA1 gene mutation carriers, bilateral prophylactic mastectomy at age 25 years yields a $13 \%$ gain relative to no intervention, whereas delaying prophylactic mastectomy to age 40 years yields a small (2\%) decrement in gain compared with prophylactic mastectomy at age 25 years. In BRCA2 gene mutation carriers, the reduction in mortality decreases to $8 \%$ (from $79 \%$ to $71 \%$ ) only at age 25 years compared with no intervention; postponing prophylactic mastectomy to age 40 years reduces gain by $1 \%$. This study considers prophylactic mastectomy the most effective single intervention in overall survival in BRCA2 gene mutation carriers. Moreover, in 2012, Sigal et al. ${ }^{[57]}$ applied their previously developed Monte Carlo simulation model to measure the effect of many factors on the gains in life expectancy resulted from conducting prophylactic strategies. Delaying prophylactic mastectomy by $5-10$ years could decrease the gain in life expectancy by a range from 1 to 9.9 years in BRCA1 gene mutation carriers and from 0.5 to 4.2 years in BRCA2 gene mutation carriers. In conclusion, all these studies suggest a substantial gain in life expectancy after bilateral prophylactic mastectomy. This benefit decreases with age. Studies reporting the impact of bilateral mastectomy are listed in Table 2.

surgical morbidity of bilateral prophylactic mastectomy

In a study in 1997 of 92 women who underwent prophylactic mastectomy followed by breast implantation, the rate of complications was $17.3 \%$ at 1 year and $30.4 \%$ at 5 years in women who received implants after prophylactic mastectomy 


\begin{tabular}{|c|c|c|}
\hline Study (author, year) & Population & Main findings \\
\hline Meijers-Heijboer et al., 200|[46] & $\mathrm{BRCAI} / 2$ & Decreased incidence of $B C$ after $P M(H R=0 ; 95 \% C l=0-0.36 ; P=0.003)$ \\
\hline Hartmann et al., $\left.200\right|^{[4]]}$ & $\mathrm{BRCAI} / 2$ & $\begin{array}{l}\text { Reduction in observed risk of } \mathrm{BC} \text { after } \mathrm{PM}=89.5 \%(95 \% \\
\mathrm{Cl}=4 \mid .4 \%-99.7 \%)-100 \%(95 \% \mathrm{Cl}=68.0 \%-100.0 \%)\end{array}$ \\
\hline Rebbeck et al., 2004[48] & BRCAI/2 & Decreased incidence of $B C$ after PM $(H R=0.05-0.09 ; P<0.00 I)$ \\
\hline Domchek et al., 2010 $0^{[49]}$ & $\mathrm{BRCAI} / 2$ & Decreased risk of BC after PM \\
\hline Manning et al., $2015^{[44]}$ & $\mathrm{BRCAI} / 2$ & No newly diagnosed breast cancers \\
\hline Hartmann et al., $19999^{[50]}$ & History of BC & Reduction in risk of $B C$ after $P M, 89.5 \% ;(P<0.00 I)$ \\
\hline Geiger et al., 2005[51] & $\begin{array}{l}\text { Family history, history of atypical } \\
\text { hyperplasia, or } \geq \text { I benign breast biopsies }\end{array}$ & Decreased incidence of $\mathrm{BC}$ after $\mathrm{PM}(\mathrm{HR}=0.005 ; 95 \% \mathrm{Cl}=0.00 \mathrm{I}-0.044)$ \\
\hline King et al., $2015^{[52]}$ & LCIS & No newly diagnosed breast cancers \\
\hline Schrag et al., $1997^{[54]}$ & $\mathrm{BRCAI} / 2$ & Suggested 2.9-5.3 year gain in life expectancy after PM \\
\hline Grann et al., $2002^{[55]}$ & $\mathrm{BRCAI} / 2$ & Suggested 3.5 years gain in life expectancy after PM \\
\hline Kurian et al., 20I0[56] & $\mathrm{BRCAI} / 2$ & $\begin{array}{l}\text { Suggested I } 3 \% \text { gain in life expectancy in BRCAI and } 8 \% \text { in BRCA2 after } \\
\text { PM at age } 25 \text { years }\end{array}$ \\
\hline Sigal et al., $2012^{[57]}$ & $\mathrm{BRCAI} / 2$ & $\begin{array}{l}\text { I-9.9 year decreased gain in life expectancy in BRCAI and } 0.5-4.2 \text { year } \\
\text { in BRCA2 with delaying PM by } 5-10 \text { year }\end{array}$ \\
\hline
\end{tabular}

during a mean follow-up of 7.8 years. The most frequent problems were capsular contraction, implant rupture, hematoma, and wound infection, respectively. ${ }^{[58]}$ However, 1 year later, a study measured the overall satisfaction rate among women who had bilateral prophylactic mastectomy, and it reported that only $5 \%$ of 370 women expressed regrets about the procedure over a median follow-up of 14.6 years. $^{[59]}$

\section{Ipsilateral}

\section{Ductal carcinoma in situ}

Most of the patients with DCIS are treated with breast-conserving surgery. However, one-third of patients undergo mastectomy. Data from SEER registries showed steady decline in the use of mastectomy for treatment of DCIS from 43\% in 1992 to $28 \%$ in 1999 with significant variations among SEER sites. ${ }^{[60,61]}$ A number of recent studies have evaluated the impact of mastectomy for the treatment of DCIS regarding recurrence and survival. In 2011, a total of 496 patients with pure DCIS were prospectively followed-up a median of 83 months after treatment with mastectomy. Eleven (2\%) patients with multifocal disease and comedo-type necrosis developed recurrences. ${ }^{[62]}$ A 10-year follow-up prospective study conducted in 2012 showed only one case of distant recurrence of a lesion that originally was high-grade DCIS among 54 patients. None of whom developed locoregional or local recurrence. ${ }^{[63]}$ Another retrospective study of 803 patients with DCIS followed-up for 6.3 years showed 1\% 10-year rate for locoregional recurrence and $6.4 \%$ for contralateral breast cancer. ${ }^{[64]} \mathrm{A}$ large prospective study involving 2894 women diagnosed with DCIS was conducted in 2015. As a result of a median follow-up of 9 years, $45(1.6 \%)$ patients had an ipsilateral further event, and 83 (2.9\%) had a contralateral event. ${ }^{[65]}$ In addition to recurrence, two more retrospective studies evaluated survival in this group of patients. The first study of 637 patients with DCIS treated with mastectomy showed a cancer-specific survival of $98.0 \%$ and overall survival of 90.3\%. ${ }^{[66]}$ The second study of 1546 participants showed consistent results. ${ }^{[67]}$ Other studies reporting comparable results are listed in Table 3.

Data regarding attribution of factors such as age, resection margin status, microinvasion, comedo-necrosis, tumor grade, tumor size or multifocal or multicentric tumor on the risk of recurrence are conflicting and not clear enough to guide the use of chest wall radiation post mastectomy. ${ }^{[62,64,66,67,69,70,75-77]}$

\section{Lobular carcinoma in situ}

Unlike the current trend, women diagnosed with LCIS were often treated with mastectomy. ${ }^{[78,79]}$ The shift toward more conservative measures resulted from data suggesting a lower estimated risk of breast cancer in these women. ${ }^{[80]} \mathrm{A}$ group of studies conducted in the 1960s and 1970s compared the results of patients treated with mastectomy and those under surveillance. A study including 124 patients with LCIS; 105 underwent mastectomy and 19 kept under follow-up, showed 1 infiltrating lobular carcinoma (IFLC) in the mastectomy group and two in the surveillance group. ${ }^{[81]}$ Similarly, in another study with a median follow-up period of 16 years, six patients treated with mastectomy were compared to 40 patients underwent diagnostic biopsy only, 15 recurrences were observed in the second group; nearly $75 \%$ of which were infiltrating and 50\% appeared in the first 10 years. No recurrences were observed in the mastectomy group. ${ }^{[82]}$ In 2015, a study compared the results of 24 patients who underwent mastectomy alone, 159 patients who underwent breast conservative surgery alone and 17 patients who underwent breast conservative surgery and radiation. In 
the breast conservative surgery group, 20 (13\%) patients developed local recurrence by 6 years, and by 10 years, the rate increased to $17.5 \%$. After 12 years of follow-up of the other two groups, three patients (17\%) in the breast conservative surgery and radiation group developed local recurrence, while no recurrence was observed in the mastectomy group. ${ }^{[83]}$ Studies reporting the impact of ipsilateral mastectomy on recurrence in LCIS are listed in Table 4.

\section{Phyllodes}

Until the late 1970s, phyllode tumors were mainly treated with mastectomy, regardless of tumor size or grade. ${ }^{[88]}$ However, recent data consider cautious breast conservative surgery reasonably successful in providing results comparable to mastectomy. ${ }^{[89]}$ A study analyzed changes in the management of phyllodes in the period between 1952 and 2007 and correlated them to patient's outcomes showed a significant increase in a number of women undergoing breast conservative surgery instead of mastectomy. Despite this, there was no increase of disease at 5 -year survival. ${ }^{[00]}$ Table 5 shows a number of studies comparing different surgical approaches to benign and borderline phyllodes.
One study conducted in 1996 evaluated the impact of wide local resection and mastectomy on the survival of patients with benign and borderline phyllodes. In the wide local resection group, 78 (98.7\%) of 79 patients with benign type were found with no evidence of disease at 5-year survival, compared to 10 (76.9\%) of 13 in the mastectomy group. In patients with borderline type, $12(80 \%)$ of 15 were found with no evidence of disease at 5-year survival in the wide local resection group compared with 2 (50\%) of 4 for the mastectomy. ${ }^{[95]}$ Tumor size was not correlated with histopathological type, the rate of recurrence or deaths. ${ }^{[91]}$ In conclusion, most of the evidence support the use mastectomy only when tumor size in relation to breast volume is large and cannot be resected with acceptable cosmetic and oncologic outcomes. ${ }^{[91,95]}$

No studies evaluated the addition of postmastectomy radiation in the prophylactic use.

\section{Contralateral BRCA}

A retrospective cohort of 148 women was published by van Sprundel et al. ${ }^{[96]}$ shows the clinical outcome of

\begin{tabular}{|c|c|c|c|c|c|}
\hline Study (author, year) & Type & $\begin{array}{l}\text { Median } \\
\text { follow-up }\end{array}$ & Intervention & $\begin{array}{l}\text { Number of } \\
\text { patients }\end{array}$ & Recurrences \\
\hline Rubio et al., 2000"[68] & Retrospective & 3.7 years & SSM & 95 & $3 \mathrm{LR}$ \\
\hline Carlson et al., 2007[69] & Retrospective & 6.3 years & SSM & 223 & $7 \mathrm{LR}, 2 \mathrm{RR}$ and $2 \mathrm{DR}$ \\
\hline Rashtian et al., 2008 ${ }^{[70]}$ & Retrospective & 61 months & Mastectomy & 574 & 80 LR \\
\hline Godat et al., 2009[7]] & Retrospective & 4.5 years & Mastectomy & 83 & 0 \\
\hline Reefy et al., 2010[72] & Prospective & 36 months & SSM & 25 & 0 \\
\hline Kelley et al., $\left.201\right|^{[62]}$ & Prospective & 83 months & Mastectomy & 496 & 11 \\
\hline de Alcantara Filho et al., 20 I | ${ }^{[73]}$ & Prospective & 10.38 months & NSM & 74 & 0 \\
\hline Chan et al., 20I I [74] & Retrospective & 8 years & Mastectomy & 193 & $2 \mathrm{CWR}$ \\
\hline Childs et al., $2013^{[75]}$ & Retrospective & 7.6 years & Mastectomy & 142 & 2 \\
\hline Romics et al., $2012^{[63]}$ & Prospective & 10 years & SSM & 54 & $2 \mathrm{DR}$ \\
\hline Chadha et al., $2012^{[76]}$ & Retrospective & 55 months & Mastectomy & 211 & 2 locoregional recurrences \\
\hline Clements et al., 2015 $5^{[65]}$ & Prospective & 9 years & Mastectomy & 2894 & 45 ipsilateral and 83 contralateral recurrences \\
\hline Klein et al., 2015[67] & Retrospective & 10 years & Mastectomy & 1546 & $36 \mathrm{CWR}$ \\
\hline Bannani et al., 20I5 $5^{[77]}$ & Retrospective & 39 months & Mastectomy & 210 & 6 locoregional and 2 DR \\
\hline
\end{tabular}

\begin{tabular}{|c|c|c|c|c|}
\hline Study (author, year) & Median follow-up & Intervention & Number of patients & Recurrence \\
\hline Benfield et al., $1965^{[84]}$ & 6.5 years & Mastectomy & 13 & 0 \\
\hline Farrow, $1968^{[85]}$ & NA & MRM & 161 & 0 \\
\hline \multirow{2}{*}{ Hutter and Foote, $1969^{[82]}$} & 16 years & Radical mastectomy & 6 & 0 \\
\hline & & Diagnostic biopsy & 40 & $15 ; 75 \%$ infiltrating \\
\hline Donegan and Perez-Mesa, $1972^{[86]}$ & 21 months & Mastectomy & 35 & 9 \\
\hline \multirow[t]{2}{*}{ Giordano and Klopp, $1973^{[81]}$} & NA & Simple mastectomy & 105 & I infiltrating \\
\hline & & Careful follow-up & 19 & 2 infiltrating \\
\hline \multirow[t]{2}{*}{ Wheeler et al., 1974 ${ }^{[87]}$} & I5.7 months & Simple or radical mastectomy & 13 & 0 \\
\hline & & Careful follow-up & 25 & I infiltrating \\
\hline \multirow[t]{3}{*}{ Cutuli et al., 2015 $5^{[83]}$} & 12 years & Mastectomy only & 24 & 0 \\
\hline & & BCS and WBRT & 17 & $3(17 \%)$ LR \\
\hline & 6 years & BCS only & 159 & $20(13 \%)$ LR \\
\hline
\end{tabular}




\begin{tabular}{|c|c|c|c|c|}
\hline Study (author, year) & $\begin{array}{l}\text { Median follow-up } \\
\text { (benign/borderline) } \\
\text { (months) }\end{array}$ & Intervention & $\begin{array}{l}\text { Number of patients } \\
\text { (benign/borderline) }\end{array}$ & LR (benign/borderline) \\
\hline \multirow[t]{4}{*}{ Salvadori et al., 1989[9]] } & $106 / 84$ & WLE & $24 / 22$ & $1 / 10$ \\
\hline & & MRM & $1 / 0$ & $0 / 0$ \\
\hline & & Subcutaneous mastectomy & $0 / 2$ & $0 / 0$ \\
\hline & & Total mastectomy & $0 / 2$ & $0 / 0$ \\
\hline \multirow[t]{3}{*}{ Moffat et al., 1995 } & 135 & Local excision & $16 / 1$ & $6 / 0$ \\
\hline & & Simple mastectomy & $5 / 2$ & $0 / 0$ \\
\hline & & Subcutaneous mastectomy & $2 / 1$ & $0 / 0$ \\
\hline \multirow[t]{2}{*}{ Acar et al., 20I5 $5^{[93]}$} & 46 & WLE & $11 / 3$ & $0 / 0$ \\
\hline & & Mastectomy & $0 / 2$ & $0 / 0$ \\
\hline \multirow[t]{3}{*}{ Toh et al., 20I6 $6^{[94]}$} & $44.2 / 26.5$ & BCS & $17 / 2$ & $2 / 0$ \\
\hline & & Simple mastectomy & $1 / 0$ & $0 / 0$ \\
\hline & & $\begin{array}{l}\text { Mastectomy with axillary } \\
\text { clearance }\end{array}$ & $3 / 2$ & $0 / 0$ \\
\hline
\end{tabular}

contralateral prophylactic mastectomy in BRCA1 and 2 gene mutation carries with the previous history of stage I-IIIa breast cancer. Seventy-nine of the 148 women underwent contralateral prophylactic mastectomy, while the other 69 remained under regular surveillance. After a mean follow-up of 3.5 years, one women only developed an invasive contralateral primary breast cancer after the contralateral prophylactic mastectomy, whereas 6 women were diagnosed with breast cancer in the surveillance group. Another study compared 146 women treated with bilateral, prior, or delayed contralateral mastectomy with 336 women who retained the contralateral breast. As a result of a median follow-up of 9.2 years, only 1 contralateral chest wall recurrence was found in the first group while 97 contralateral breast cancers were found in the second (hazard ratio $=0.03$ ). ${ }^{[97]}$ The populations of the two previous studies included variant histological types of breast cancer with infiltrating ductal carcinoma composing more than $60 \%$ in both of them. In a recent prospective study conducted by Manning et al., ${ }^{[44]}$ 26 BRCA gene mutation carriers of median age 41 years had contralateral prophylactic nipple-sparing mastectomy. At a median follow-up of 28 months, there were no local or regional recurrences in any of these women.

\section{Non-BRCA}

Peralta et al. ${ }^{[98]}$ compared 64 women with a personal history of infiltrating ductal carcinoma (63\%), IFLC (19\%), LCIS (9\%) or DCIS (5\%) who underwent contralateral prophylactic mastectomy with 182 matching controls. After 6.2 years of follow-up, 36 contralateral breast cancers were found in the control group. While in the contralateral prophylactic mastectomy group, three occult cancers were found in the contralateral breast at the time of the surgery, but none developed subsequently $(P=0.005)$. Herrinton et al. ${ }^{[99]}$ conducted a large retrospective cohort comprised approximately 50,000 women in 2005. In women with contralateral prophylactic mastectomy, $0.5 \%$ of women developed contralateral breast cancer, $10.5 \%$ of women developed metastatic disease and $12.4 \%$ developed subsequent breast cancer; $8.1 \%$ of women died of breast cancer. In comparison, $2.7 \%$ of women without contralateral prophylactic mastectomy developed contralateral breast cancer and 11.7 died of the disease. A more recent study composed of 385 patients with stage I or II breast cancer and a family history of breast cancer defined as parent, sibling, or second-degree relative with breast cancer who underwent contralateral prophylactic mastectomy and the same number of matching controls showed $2(0.5 \%)$ contralateral breast cancers developed in the contralateral prophylactic mastectomy group and 31 (8.1\%) in the control group, representing a $95 \%$ decreased risk of contralateral breast cancer (hazard ratio $=0.05,95 \%$ confidence interval $0.01-0.22) .{ }^{[100]}$

\section{Infiltrating lobular carcinoma}

One study published in 1997 compared the efficacy of contralateral prophylactic mastectomy to the conservative measures in IFLC specifically, by following 18 patients who underwent contralateral prophylactic mastectomy and 115 patients who did not for a median of 68 months. Three (3\%) contralateral cancers were detected in the conservative group and 3 (17\%) LCIS only in the contralateral prophylactic mastectomy group, concluding that careful follow-up is an acceptable choice for patents with IFLC. ${ }^{[101]}$ Studies reporting the impact of contralateral mastectomy are listed in Table 6.

\section{QUALITY OF LIFE AFTER MASTECTOMY}

Although mastectomies, in general, have low morbidity, decrease cancer-specific distress and improve symmetry in the case of contralateral mastectomies, women still experience long-term effects. ${ }^{[102-104]}$ Cosmetic, psychological, 


\begin{tabular}{|c|c|c|}
\hline Study (author, year) & Population & Main findings \\
\hline Metcalfe, 2004 & $\mathrm{BRCAI} / 2$ & Decreased occurrence of $C B C$ after $P M(H R=0.03 ; P=0.0005)$ \\
\hline van Sprundel, 2005 ${ }^{[96]}$ & $\mathrm{BRCAI} / 2$ & Decreased occurrence of $C B C$ after PM $(P<0.00 I)$ \\
\hline Manning, 20I5 $5^{[4]}$ & $\mathrm{BRCAI} / 2$ & No newly diagnosed breast cancers \\
\hline Peralta, $2000^{[98]}$ & Unilateral BC & Decreased occurrence of $C B C$ after $P M(P=0.005)$ \\
\hline Herrinton, $2005^{[99]}$ & Unilateral BC & Decreased occurrence of $\mathrm{CBC}$ after $\mathrm{CPM}(\mathrm{HR}=0.03 ; 95 \% \mathrm{Cl}=0.006-0.13)$ \\
\hline Boughey, $2010^{[100]}$ & Stage I or II BC and family history & $95 \%$ decreased risk of $\mathrm{CBC}(\mathrm{HR}=0.05 ; 95 \% \mathrm{Cl}=0.0 \mathrm{I}-0.22 ; P<0.000 \mathrm{I})$ \\
\hline Babiera, 1997[101] & IFLC & No significant difference in DFS between mastectomy and conservation $(P=0.98)$ \\
\hline
\end{tabular}

and social domains are likely to be impacted. When patients were asked about general satisfaction with their decision, women who had mastectomies showed high satisfaction rates reaching $70 \%$ after 14.5 years of bilateral mastectomy and ranging between $83 \%$ and $90 \%$ after $10.3-$ 20 years of contralateral mastectomies. ${ }^{[105-107]}$ However, body image issues were significantly affected, especially with bilateral mastectomies due to many factors, such as self-consciousness, feeling less sexually attractive, and dissatisfaction with the scars. ${ }^{[103,104,107-109]}$ Decreased sexual satisfaction was linked to both body image issues and loss of sensation in the breast. ${ }^{[110]}$ Even after long periods of time; one study showed that $36 \%$ of the women are still having problems with their body image after 14 years of bilateral mastectomies. ${ }^{[106]}$ Body appearance was the major issue in contralateral mastectomies as well. ${ }^{[105,107]}$ Women who underwent unilateral mastectomies were less satisfied by their appearance than women who underwent bilateral mastectomies. Some data suggest that reconstruction is associated with less satisfaction in the long-term, explained by more frequent surgical complications and concerns about implants. ${ }^{[106]}$ This side of prophylactic mastectomies should be highlighted to women considering the surgery so that they can weigh the benefits alongside the potential adverse effects.

\section{CONCLUSION}

The majority of evidence confirms $85 \%$ to $100 \%$ reduction in the incidence of breast cancer after prophylactic bilateral and contralateral mastectomy. However, prophylactic ipsilateral mastectomy has not been shown to eliminate the risk of recurrence, and in most cases, it is not supported unless surgically indicated. Because many of breast cancers are detected at an early stage where patients show good prognosis, absolute survival benefits would require studies with larger number of patients and longer periods of follow-up. Although mastectomy is generally safe and associated with high satisfaction rate, careful risk estimation, and selection of individuals who will benefit from preventing breast cancer is necessary to minimize morbidity to the reminder.
Financial support and sponsorship

Nil.

\section{Conflicts of interest}

There are no conflicts of interest.

\section{REFERENCES}

1. Siegel RL, Miller KD, Jemal A. Cancer statistics, 2016. CA Cancer J Clin 2016;66:7-30.

2. SEER Cancer Statistics Review 1975-2014. National Cancer Institute. Available from: https://www.seer.cancer.gov/csr/1975_2014/results merged/sect_04_breast.pdf. [Last accessed on 2017 Oct 09].

3. Basu NN, Barr L, Ross GL, Evans DG. Contralateral risk-reducing mastectomy: Review of risk factors and risk-reducing strategies. Int J Surg Oncol 2015;2015:901046.

4. Colleoni M, Sun Z, Price KN, Karlsson P, Forbes JF, Thürlimann B, et al. Annual hazard rates of recurrence for breast cancer during 24 years of follow-up: Results from the international breast cancer study group trials I to V. J Clin Oncol 2016;34:927-35.

5. Ghosh K, Hartmann LC. Current status of prophylactic mastectomy. Oncology (Williston Park) 2002;16:1319-25.

6. Balmaña J, Díez O, Rubio IT, Cardoso F; ESMO Guidelines Working Group. BRCA in breast cancer: ESMO clinical practice guidelines. Ann Oncol 2011;22 Suppl 6:vi31-4.

7. Moynahan ME, Chiu JW, Koller BH, Jasin M. Brca1 controls homology-directed DNA repair. Mol Cell 1999;4:511-8.

8. Scully R, Chen J, Plug A, Xiao Y, Weaver D, Feunteun J, et al. Association of BRCA1 with rad51 in mitotic and meiotic cells. Cell 1997;88:265-75.

9. Aparicio T, Baer R, Gautier J. DNA double-strand break repair pathway choice and cancer. DNA Repair (Amst) 2014;19:169-75.

10. Moynahan ME, Pierce AJ, Jasin M. BRCA2 is required for homology-directed repair of chromosomal breaks. Mol Cell 2001;7:263-72.

11. Patel KJ, Yu VP, Lee H, Corcoran A, Thistlethwaite FC, Evans MJ, et al. Involvement of brca2 in DNA repair. Mol Cell 1998;1:347-57.

12. Venkitaraman AR. Cancer susceptibility and the functions of BRCA1 and BRCA2. Cell 2002;108:171-82.

13. Antoniou A, Pharoah PD, Narod S, Risch HA, Eyfjord JE, Hopper JL, et al. Average risks of breast and ovarian cancer associated with BRCA1 or BRCA2 mutations detected in case series unselected for family history: A combined analysis of 22 studies. Am J Hum Genet 2003;72:1117-30.

14. Chen S, Parmigiani G. Meta-analysis of BRCA1 and BRCA2 penetrance. J Clin Oncol 2007;25:1329-33.

15. van der Kolk DM, de Bock GH, Leegte BK, Schaapveld M, Mourits MJ, de Vries J, et al. Penetrance of breast cancer, ovarian cancer and contralateral breast cancer in BRCA1 and BRCA2 families: High cancer incidence at older age. Breast Cancer Res Treat 2010;124:643-51.

16. Mavaddat N, Peock S, Frost D, Ellis S, Platte R, Fineberg E, et al. Cancer risks for BRCA1 and BRCA2 mutation carriers: Results from prospective 
analysis of EMBRACE. J Natl Cancer Inst 2013;105:812-22.

17. Caminsky NG, Mucaki EJ, Perri AM, Lu R, Knoll JH, Rogan PK. Prioritizing variants in complete hereditary breast and ovarian cancer (HBOC) genes in patients lacking known BRCA mutations. Hum Mutat. 2016;37:640-52.

18. Levine AJ. P53, the cellular gatekeeper for growth and division. Cell 1997;88:323-31.

19. Llort G, Chirivella I, Morales R, Serrano R, Sanchez AB, Teulé A, et al. SEOM clinical guidelines in hereditary breast and ovarian cancer. Clin Transl Oncol 2015;17:956-61.

20. Ochs-Balcom HM, Marian C, Nie J, Brasky TM, Goerlitz DS, Trevisan M, et al. Adiposity is associated with p53 gene mutations in breast cancer. Breast Cancer Res Treat 2015;153:635-45.

21. Ngeow J, Sesock K, Eng C. Breast cancer risk and clinical implications for germline PTEN mutation carriers. Breast Cancer Res Treat 2017;165:1-8.

22. Tan MH, Mester JL, Ngeow J, Rybicki LA, Orloff MS, Eng C, et al. Lifetime cancer risks in individuals with germline PTEN mutations. Clin Cancer Res 2012;18:400-7.

23. Worsham MJ, Abrams J, Raju U, Kapke A, Lu M, Cheng J, et al. Breast cancer incidence in a cohort of women with benign breast disease from a multiethnic, primary health care population. Breast J 2007;13:115-21.

24. Hartmann LC, Sellers TA, Frost MH, Lingle WL, Degnim AC, Ghosh K, et al. Benign breast disease and the risk of breast cancer. $\mathrm{N}$ Engl J Med 2005;353:229-37.

25. Dupont WD, Page DL. Risk factors for breast cancer in women with proliferative breast disease. N Engl J Med 1985;312:146-51.

26. London SJ, Connolly JL, Schnitt SJ, Colditz GA. A prospective study of benign breast disease and the risk of breast cancer. JAMA 1992;267:941-4.

27. Coopey SB, Mazzola E, Buckley JM, Sharko J, Belli AK, Kim EM, et al. The role of chemoprevention in modifying the risk of breast cancer in women with atypical breast lesions. Breast Cancer Res Treat 2012;136:627-33.

28. Fentiman IS. 8. The dilemma of in situ carcinoma of the breast. Int J Clin Pract 2001;55:680-3.

29. Silverstein MJ, Rosser RJ, Gierson ED, Waisman JR, Gamagami P, Hoffman RS, et al. Axillary lymph node dissection for intraductal breast carcinoma - Is it indicated? Cancer 1987;59:1819-24.

30. Page DL, Dupont WD, Rogers LW, Jensen RA, Schuyler PA. Continued local recurrence of carcinoma 15-25 years after a diagnosis of low grade ductal carcinoma in situ of the breast treated only by biopsy. Cancer 1995;76:1197-200.

31. Guillot E, Vaysse C, Goetgeluck J, Falcou MC, Couturaud B, Fitoussi A, et al. Extensive pure ductal carcinoma in situ of the breast: Identification of predictors of associated infiltrating carcinoma and lymph node metastasis before immediate reconstructive surgery. Breast 2014;23:97-103.

32. Han JS, Molberg KH, Sarode V. Predictors of invasion and axillary lymph node metastasis in patients with a core biopsy diagnosis of ductal carcinoma in situ: An analysis of 255 cases. Breast J 2011;17:223-9.

33. Yen TW, Hunt KK, Ross MI, Mirza NQ, Babiera GV, Meric-Bernstam F, et al. Predictors of invasive breast cancer in patients with an initial diagnosis of ductal carcinoma in situ: A guide to selective use of sentinel lymph node biopsy in management of ductal carcinoma in situ. J Am Coll Surg 2005;200:516-26.

34. Bhatia S, Yasui Y, Robison LL, Birch JM, Bogue MK, Diller L, et al. High risk of subsequent neoplasms continues with extended follow-up of childhood Hodgkin's disease: Report from the late effects study group. J Clin Oncol 2003;21:4386-94.

35. Healey EA, Cook EF, Orav EJ, Schnitt SJ, Connolly JL, Harris JR, et al. Contralateral breast cancer: Clinical characteristics and impact on prognosis. J Clin Oncol 1993;11:1545-52.

36. Rosen PP, Groshen S, Kinne DW, Hellman S. Contralateral breast carcinoma: An assessment of risk and prognosis in stage I (T1NOM0) and stage II (T1N1M0) patients with 20-year follow-up. Surgery 1989;106:904-10.

37. Fracchia AA, Borgen PI. Bilateral breast cancer. Semin Surg Oncol 1991;7:300-5.

38. Morrow M, Mehrara B. Prophylactic mastectomy and the timing of breast reconstruction. Br J Surg 2009;96:1-2.

39. Tuttle TM, Habermann EB, Grund EH, Morris TJ, Virnig BA. Increasing use of contralateral prophylactic mastectomy for breast cancer patients: A trend toward more aggressive surgical treatment. J Clin Oncol 2007;25:5203-9.

40. Newman LA, Kuerer HM, Hung KK, Vlastos G, Ames FC, Ross MI, et al. Prophylactic mastectomy. J Am Coll Surg 2000;191:322-30.

41. Euhus DM, Diaz J. Breast cancer prevention. Breast J 2015;21:76-81.

42. Breast Cancer Risk Reduction-v1. National Comprehensive Cancer Network; 2017. Available from: https://www.nccn.org/professionals/ physician_gls/pdf/breast_risk.pdf. [Last accessed on 2017 Oct 09].

43. Soybir G, Fukuma E. Endoscopy assisted oncoplastic breast surgery (EAOBS). J Breast Health 2015;11:52-8.

44. Manning AT, Wood C, Eaton A, Stempel M, Capko D, Pusic A, et al. Nipple-sparing mastectomy in patients with BRCA1/2 mutations and variants of uncertain significance. Br J Surg 2015;102:1354-9.

45. Warren Peled A, Foster RD, Stover AC, Itakura K, Ewing CA, Alvarado M, et al. Outcomes after total skin-sparing mastectomy and immediate reconstruction in 657 breasts. Ann Surg Oncol 2012;19:3402-9.

46. Meijers-Heijboer H, van Geel B, van Putten WL, Henzen-Logmans SC, Seynaeve C, Menke-Pluymers MB, et al. Breast cancer after prophylactic bilateral mastectomy in women with a BRCA1 or BRCA2 mutation. N Engl J Med 2001;345:159-64.

47. Hartmann LC, Sellers TA, Schaid DJ, Frank TS, Soderberg CL, Sitta DL, et al. Efficacy of bilateral prophylactic mastectomy in BRCA1 and BRCA2 gene mutation carriers. J Natl Cancer Inst 2001;93:1633-7.

48. Rebbeck TR, Friebel T, Lynch HT, Neuhausen SL, van ‘t Veer L, Garber JE, et al. Bilateral prophylactic mastectomy reduces breast cancer risk in BRCA1 and BRCA2 mutation carriers: The PROSE study group. J Clin Oncol 2004;22:1055-62.

49. Domchek SM, Friebel TM, Singer CF, Evans DG, Lynch HT, Isaacs C, et al. Association of risk-reducing surgery in BRCA1 or BRCA2 mutation carriers with cancer risk and mortality. JAMA 2010;304:967-75.

50. Hartmann LC, Schaid DJ, Woods JE, Crotty TP, Myers JL, Arnold PG, et al. Efficacy of bilateral prophylactic mastectomy in women with a family history of breast cancer. N Engl J Med 1999;340:77-84.

51. Geiger AM, Yu O, Herrinton LJ, Barlow WE, Harris EL, Rolnick S, et al. A population-based study of bilateral prophylactic mastectomy efficacy in women at elevated risk for breast cancer in community practices. Arch Intern Med 2005;165:516-20.

52. King TA, Pilewskie M, Muhsen S, Patil S, Mautner SK, Park A, et al. Lobular carcinoma in situ: A 29-year longitudinal experience evaluating clinicopathologic features and breast cancer risk. J Clin Oncol 2015;33:3945-52.

53. Powers RW, O’Brien PH, Kreutner A Jr. Lobular carcinoma in situ. J Surg Oncol 1980;13:269-73.

54. Schrag D, Kuntz KM, Garber JE, Weeks JC. Decision analysis - Effects of prophylactic mastectomy and oophorectomy on life expectancy among women with BRCA1 or BRCA2 mutations. N Engl J Med 1997;336:1465-71.

55. Grann VR, Jacobson JS, Thomason D, Hershman D, Heitjan DF, Neugut AI, et al. Effect of prevention strategies on survival and quality-adjusted survival of women with BRCA1/2 mutations: An updated decision analysis. J Clin Oncol 2002;20:2520-9.

56. Kurian AW, Sigal BM, Plevritis SK. Survival analysis of cancer risk reduction strategies for BRCA1/2 mutation carriers. J Clin Oncol 2010;28:222-31.

57. Sigal BM, Munoz DF, Kurian AW, Plevritis SK. A simulation model to predict the impact of prophylactic surgery and screening on the life 
expectancy of BRCA1 and BRCA2 mutation carriers. Cancer Epidemiol Biomarkers Prev 2012;21:1066-77.

58. Gabriel SE, Woods JE, O'Fallon WM, Beard CM, Kurland LT, Melton LJ $3^{\text {rd }}$, et al. Complications leading to surgery after breast implantation. $\mathrm{N}$ Engl J Med 1997;336:677-82.

59. Borgen PI, Hill AD, Tran KN, Van Zee KJ, Massie MJ, Payne D, et al. Patient regrets after bilateral prophylactic mastectomy. Ann Surg Oncol 1998;5:603-6.

60. Baxter NN, Virnig BA, Durham SB, Tuttle TM. Trends in the treatment of ductal carcinoma in situ of the breast. J Natl Cancer Inst 2004;96:443-8.

61. Joslyn SA. Ductal carcinoma in situ: Trends in geographic, temporal, and demographic patterns of care and survival. Breast J 2006;12:20-7.

62. Kelley L, Silverstein M, Guerra L. Analyzing the risk of recurrence after mastectomy for DCIS: A new use for the USCNan nuys prognostic index. Ann Surg Oncol 2011;18:459-62.

63. Romics L Jr., Chew BK, Weiler-Mithoff E, Doughty JC, Brown IM, Stallard S, et al. Ten-year follow-up of skin-sparing mastectomy followed by immediate breast reconstruction. Br J Surg 2012;99:799-806.

64. Fitzsullivan E, Lari SA, Smith B, Caudle AS, Krishnamurthy S, Lucci A, et al. Incidence and consequence of close margins in patients with ductal carcinoma-in situ treated with mastectomy: Is further therapy warranted? Ann Surg Oncol 2013;20:4103-12.

65. Clements K, Dodwell D, Lawrence G, Ball G, Francis A, Pinder S, et al. Radiotherapy after mastectomy for screen-detected ductal carcinoma in situ. Eur J Surg Oncol 2015;41:1406-10.

66. Owen D, Tyldesley S, Alexander C, Speers C, Truong P, Nichol A, et al. Outcomes in patients treated with mastectomy for ductal carcinoma in situ. Int J Radiat Oncol Biol Phys 2013;85:e129-34.

67. Klein J, Kong I, Paszat L, Nofech-Mozes S, Hanna W, Thiruchelvam D, et al. Close or positive resection margins are not associated with an increased risk of chest wall recurrence in women with DCIS treated by mastectomy: A population-based analysis. Springerplus 2015;4:335.

68. Rubio IT, Mirza N, Sahin AA, Whitman G, Kroll SS, Ames FC, et al. Role of specimen radiography in patients treated with skin-sparing mastectomy for ductal carcinoma in situ of the breast. Ann Surg Oncol 2000;7:544-8.

69. Carlson GW, Page A, Johnson E, Nicholson K, Styblo TM, Wood WC, et al. Local recurrence of ductal carcinoma in situ after skin-sparing mastectomy. J Am Coll Surg 2007;204:1074-8.

70. Rashtian A, Iganej S, Amy Liu IL, Natarajan S. Close or positive margins after mastectomy for DCIS: Pattern of relapse and potential indications for radiotherapy. Int J Radiat Oncol Biol Phys 2008;72:1016-20.

71. Godat LN, Horton JK, Shen P, Stewart JH, Wentworth S, Levine EA, et al. Recurrence after mastectomy for ductal carcinoma in situ. Am Surg 2009;75:592-5.

72. Reefy S, Patani N, Anderson A, Burgoyne G, Osman H, Mokbel K, et al. Oncological outcome and patient satisfaction with skin-sparing mastectomy and immediate breast reconstruction: A prospective observational study. BMC Cancer 2010;10:171.

73. de Alcantara Filho P, Capko D, Barry JM, Morrow M, Pusic A, Sacchini VS, et al. Nipple-sparing mastectomy for breast cancer and risk-reducing surgery: The memorial sloan-kettering cancer center experience. Ann Surg Oncol 2011;18:3117-22.

74. Chan LW, Rabban J, Hwang ES, Bevan A, Alvarado M, Ewing C, et al. Is radiation indicated in patients with ductal carcinoma in situ and close or positive mastectomy margins? Int J Radiat Oncol Biol Phys 2011;80:25-30.

75. Childs SK, Chen YH, Duggan MM, Golshan M, Pochebit S, Punglia RS, et al. Impact of margin status on local recurrence after mastectomy for ductal carcinoma in situ. Int J Radiat Oncol Biol Phys 2013;85:948-52.

76. Chadha M, Portenoy J, Boolbol SK, Gillego A, Harrison LB. Is there a role for postmastectomy radiation therapy in ductal carcinoma in situ? Int J Surg Oncol 2012;2012:423520.

77. Bannani S, Rouquette S, Bendavid-Athias C, Tas P, Levêque J. The locoregional recurrence post-mastectomy for ductal carcinoma in situ: Incidence and risk factors. Breast 2015;24:608-12.

78. Foote FW, Stewart FW. Lobular carcinoma in situ: A rare form of mammary cancer. Am J Pathol 1941;17:491-6.3.

79. Maluf $\mathrm{H}$, Koerner $\mathrm{F}$. Lobular carcinoma in situ and infiltrating ductal carcinoma: Frequent presence of DCIS as a precursor lesion. Int J Surg Pathol 2001;9:127-31.

80. Fisher ER, Costantino J, Fisher B, Palekar AS, Paik SM, Suarez CM, et al. Pathologic findings from the national surgical adjuvant breast project (NSABP) protocol B-17. Five-year observations concerning lobular carcinoma in situ. Cancer 1996;78:1403-16.

81. Giordano JM, Klopp CT. Lobular carcinoma in situ: Incidence and treatment. Cancer 1973;31:105-9.

82. Hutter RV, Foote FW Jr. Lobular carcinoma in situ. Long term follow-up. Cancer 1969;24:1081-5.

83. Cutuli B, De Lafontan B, Kirova Y, Auvray H, Tallet A, Avigdor S, et al. Lobular carcinoma in situ (LCIS) of the breast: Is long-term outcome similar to ductal carcinoma in situ (DCIS)? Analysis of 200 cases. Radiat Oncol 2015;10:110.

84. Benfield J, Jacobson M, Warner N. In situ lobular carcinoma of the breast. Arch Surg 1965;91:130-5.

85. Farrow JH. Clinical considerations and treatment of in situ lobular breast cancer. Am J Roentgenol Radium Ther Nucl Med 1968;102:652-6.

86. Donegan WL, Perez-Mesa CM. Lobular carcinoma - An indication for elective biopsy of the second breast. Ann Surg 1972;176:178-87.

87. Wheeler JE, Enterline HT, Roseman JM, Tomasulo JP, Mcllvaine $\mathrm{CH}$, Fitts WT Jr., et al. Lobular carcinoma in situ of the breast. Long-term followup. Cancer 1974;34:554-63.

88. Parker SJ, Harries SA. Phyllodes tumours. Postgrad Med J 2001;77:428-35.

89. Sotheran W, Domjan J, Jeffrey M, Wise MH, Perry PM. Phyllodes tumours of the breast - A retrospective study from 1982-2000 of 50 cases in portsmouth. Ann R Coll Surg Engl 2005;87:339-44.

90. Mituś JW, Blecharz P, Reinfuss M, Kulpa JK, Skotnicki P, Wysocki WM, et al. Changes in the clinical characteristics, treatment options, and therapy outcomes in patients with phyllodes tumor of the breast during 55 years of experience. Med Sci Monit 2013;19:1183-7.

91. Salvadori B, Cusumano F, Del Bo R, Delledonne V, Grassi M, Rovini D, et al. Surgical treatment of phyllodes tumors of the breast. Cancer 1989;63:2532-6.

92. Moffat CJ, Pinder SE, Dixon AR, Elston CW, Blamey RW, Ellis IO, et al. Phyllodes tumours of the breast: A clinicopathological review of thirty-two cases. Histopathology 1995;27:205-18.

93. Acar T, Tarcan E, Hacıyanlı M, Kamer E, Peşkersoy M, Yiğit S, et al. How to approach phyllodes tumors of the breast? Ulus Cerrahi Derg 2015;31:197-201.

94. Toh YF, Cheah PL, Looi LM, Teoh KH, Tan PH. Phyllodes tumours of the breast: Retrospective analysis of a university hospital's experience. Malays J Pathol 2016;38:19-24.

95. Reinfuss M, Mituś J, Duda K, Stelmach A, Ryś J, Smolak K, et al. The treatment and prognosis of patients with phyllodes tumor of the breast: An analysis of 170 cases. Cancer 1996;77:910-6.

96. van Sprundel TC, Schmidt MK, Rookus MA, Brohet R, van Asperen CJ, Rutgers EJ, et al. Risk reduction of contralateral breast cancer and survival after contralateral prophylactic mastectomy in BRCA1 or BRCA2 mutation carriers. Br J Cancer 2005;93:287-92.

97. Metcalfe K, Lynch HT, Ghadirian P, Tung N, Olivotto I, Warner E, et al. Contralateral breast cancer in BRCA1 and BRCA2 mutation carriers. J Clin Oncol 2004;22:2328-35.

98. Peralta EA, Ellenhorn JD, Wagman LD, Dagis A, Andersen JS, Chu DZ, et al. Contralateral prophylactic mastectomy improves the outcome of selected patients undergoing mastectomy for breast cancer. Am J Surg 2000;180:439-45.

99. Herrinton LJ, Barlow WE, Yu O, Geiger AM, Elmore JG, Barton MB, et al. Efficacy of prophylactic mastectomy in women with unilateral 
breast cancer: A cancer research network project. J Clin Oncol 2005;23:4275-86.

100. Boughey JC, Hoskin TL, Degnim AC, Sellers TA, Johnson JL, Kasner MJ, et al. Contralateral prophylactic mastectomy is associated with a survival advantage in high-risk women with a personal history of breast cancer. Ann Surg Oncol 2010;17:2702-9.

101. Babiera GV, Lowy AM, Davidson BS, Singletary SE. The role of contralateral prophylactic mastectomy in invasive lobular carcinoma. Breast J 1997;3:2-6.

102. Heiniger L, Butow PN, Coll J, Bullen T, Wilson J, Baylock B, et al. Long-term outcomes of risk-reducing surgery in unaffected women at increased familial risk of breast and/or ovarian cancer. Fam Cancer 2015;14:105-15.

103. Brandberg Y, Sandelin K, Erikson S, Jurell G, Liljegren A, Lindblom A, et al. Psychological reactions, quality of life, and body image after bilateral prophylactic mastectomy in women at high risk for breast cancer: A prospective 1-year follow-up study. J Clin Oncol 2008;26:3943-9.

104. den Heijer M, Seynaeve C, Timman R, Duivenvoorden HJ, Vanheusden K, Tilanus-Linthorst M, et al. Body image and psychological distress after prophylactic mastectomy and breast reconstruction in genetically predisposed women: A prospective long-term follow-up study. Eur J Cancer 2012;48:1263-8.

105. Frost MH, Slezak JM, Tran NV, Williams CI, Johnson JL, Woods JE, et al. Satisfaction after contralateral prophylactic mastectomy: The significance of mastectomy type, reconstructive complications, and body appearance. J Clin Oncol 2005;23:7849-56.

106. Frost MH, Schaid DJ, Sellers TA, Slezak JM, Arnold PG, Woods JE, et al. Long-term satisfaction and psychological and social function following bilateral prophylactic mastectomy. JAMA 2000;284:319-24.

107. Frost MH, Hoskin TL, Hartmann LC, Degnim AC, Johnson JL, Boughey JC, et al. Contralateral prophylactic mastectomy: Long-term consistency of satisfaction and adverse effects and the significance of informed decision-making, quality of life, and personality traits. Ann Surg Oncol 2011;18:3110-6.

108. Gahm J, Wickman M, Brandberg Y. Bilateral prophylactic mastectomy in women with inherited risk of breast cancer - prevalence of pain and discomfort, impact on sexuality, quality of life and feelings of regret two years after surgery. Breast 2010;19:462-9.

109. Gopie JP, Mureau MA, Seynaeve C, Ter Kuile MM, Menke-Pluymers MB, Timman R, et al. Body image issues after bilateral prophylactic mastectomy with breast reconstruction in healthy women at risk for hereditary breast cancer. Fam Cancer 2013;12:479-87.

110. Koslow S, Pharmer LA, Scott AM, Stempel M, Morrow M, Pusic AL, et al. Long-term patient-reported satisfaction after contralateral prophylactic mastectomy and implant reconstruction. Ann Surg Oncol 2013;20:3422-9. 